\title{
FOTOGRAMETRIJSKA PROCJENA VOLUMENA U SASTOJINAMA HRASTA LUŽNJAKA POKUPSKOG BAZENA
}

\author{
PHOTOGRAMMETRIC ESTIMATES OF STAND VOLUME \\ IN PEDUNCULATE OAK STANDS OF THE POKUPSKOO BASIN
}

\author{
Ivan BALENOVIĆ ${ }^{*}$, Luka JURJEVIĆ ${ }^{1}$, Krunoslav INDIR ${ }^{1}$, Ante SELETKOVIĆ ${ }^{2}$
}

\begin{abstract}
SAŽETAK
U radu je dodatno istražena i evaluirana točnost fotogrametrijske procjene volumena na razini sastojine. Konkretno, na području šuma hrasta lužnjaka Pokupskog bazena (g.j. Jastrebarski lugovi) testirana je mogućnost korištenja fotogrametrijske metode bazirane na postojećim i lako dostupnim podacima (aerosnimke, digitalni model reljefa, podaci osnove gospodarenja) kao i postojećih fotogrametrijskih modela procjene sastojinskog volumena izrađenih za šume hrasta lužnjaka Spačvanskog bazena. Iz aerosnimaka i digitalnog modela reljefa izrađen je digitalni model visine krošanja (DMVK) prostorne rezolucije $5 \mathrm{~m}$. Iz DMVK-a su dobiveni metrički podaci, koji su potom korišteni kao nezavisne varijable u modelima procjene volumena sastojine. Uspoređena je točnost procjene izvornih modela izrađenih za područje Spačvanskog bazena (SB modeli) te istih modela, ali s naknadno procijenjenim lokalnim parametrima za područje Pokupskog bazena (PB modeli). Fotogrametrijski procijenjeni volumeni validirani su s volumenom sastojina iz osnove gospodarenja. Dobiveni rezultati ukazuju na značajno poboljšanje točnosti fotogrametrijske procjene volumena kod PB modela u odnosu na SB modele. Korištenjem izvornih SB modela, volumen sastojine procijenjen je s korijenom srednje kvadratne pogreške od 18,47\%, dok je korištenjem dodatno parametriziranih PB modela volumen procijenjen s pogreškom od 12,03\%. U ovom radu prikazana fotogrametrijska metoda procjene volumena sastojina ne može zamijeniti klasične terenske metode za potrebe uređajne inventure šuma, međutim, budući da ne zahtijeva dodatna terenska mjerenja, već se u potpunosti bazira na postojećim podacima (aerosnimke, DMR, podaci osnove gospodarenja), a uz to pruža i zadovoljavajuću točnost, može poslužiti kao učinkovita i financijski isplativa metoda u slučajevima kada je u vrlo kratkom vremenu potrebno provesti inventuru nekog većeg šumskog područja.
\end{abstract}

KLJUČNE RIJEČI: aerosnimke, digitalna fotogrametrija, digitalni model visine krošanja (DMVK), volumen sastojine, inventura šuma

\section{UVOD}

\section{INTRODUCTION}

Potrajno gospodarenje šumama zahtijeva prostorno i vremenski određene informacije o stanju i razvoju šume koje se uglavnom prikupljaju u okviru inventure šuma, i to tradicionalno, terenskom izmjerom koja pruža točne infor- macije, ali zahtijeva dugotrajan i intenzivan rad. Upravo iz tog razloga prepoznat je potencijal uporabe metoda daljinskog istraživanja pri izmjeri šuma (White i dr. 2016, Goodbody i dr. 2019). Između različitih metoda daljinskih istraživanja, posljednja tri desetljeća zračno lasersko skeniranje (ALS, prema engl. Aiborne Laser Scanning) temeljeno na

\footnotetext{
'Dr.sc. Ivan Balenović, Dr.sc. Luka Jurjević, Dr.sc. Krunoslav Indir, Hrvatski šumarski institut, Zavod za uređivanje šuma i šumarsku ekonomiku, Croatian Forest Research Institute, Division for Forest Management and Forestry Economics, Trnjanska cesta 35, HR-10000 Zagreb, Hrvatska, ivanb@sumins.hr

${ }^{2}$ Prof.dr.sc. Ante Seletković, Sveučilište u Zagrebu, Fakultet šumarstva i drvne tehnologije, Zavod za izmjeru i uređivanje šuma, University of Zagreb, Faculty of Forestry and Wood Technology, Department of Forest Inventory and Management, Svetošimunska 25, HR-10002 Zagreb, Hrvatska
} 
LiDAR (prema engl. Light Detection and Ranging) tehnologiji zauzima velik interes istraživača diljem svijeta te danas nalazi operativnu primjenu u šumarstvu gospodarski razvijenih zemalja u kojima se LiDAR podaci redovno prikupljaju i ažuriraju na nacionalnoj razini (npr. Finska, Norveška, Švedska) (Næsset 2014, Rahlf i dr. 2014). Rezultat zračnog laserskog skeniranja je visoko precizni trodimenzionalni (3D) oblak točaka koji omogućuje izradu niza proizvoda korisnih u izmjeri šuma i šumarstvu općenito. Klasifikacijom oblaka točaka, tj. iz prvog ili jedinog odbitka izrađuje se digitalni model površine krošanja (DMPK, engl. digital surface model - DSM), a iz točaka klasificiranih kao tlo izrađuje se digitalni model reljefa (DMR, engl. digital terrain model - DTM). Upravo ta mogućnost laserskih zraka da u šumskim sastojinama 'prodiru' do samog tla predstavlja jednu od glavnih prednosti LiDAR tehnologije u odnosu na ostale metode daljinskih istraživanja. Preklapanjem DMR-a i DMPK-a, odnosno oduzimanjem DMR-a od DMPK-a dobije se digitalni model visina krošanja (DMVK, engl. canopy height model - CHM) (Lim i dr. 2003, Reutebuch i dr. 2005, Balenović i dr. 2013, White i dr. 2016).

Uz zračno lasersko skeniranje, unazad posljednjih 10-ak godina, veliku pozornost zauzimaju istraživanja o mogućnosti korištenja oblaka točaka, DMPK-a i DMVK-a dobivenih fotogrametrijskim procesiranjem aerosnimaka (Balenović i dr. 2011, White i dr. 2013, 2016, Goodbody i dr. 2019). Tome je posebno doprinio konstantni napredak i poboljšanje kvalitete snimaka (radiometrijska i geometrijska rezolucija), razvoj naprednih algoritama obrade aerosnimaka, poboljšanje kapaciteta i snage računala, ali i činjenica da su troškovi aerosnimanja znatno niži od troškova zračnog laserskog skeniranja (White i dr. 2013, 2016, Rahlf i dr. 2014, Stepper i dr. 2015, Goodbody i dr. 2019). Osim toga, za razliku od zračnog laserskog skeniranja, periodička aerosnimanja se u mnogim zemljama Europe, uključujući i Hrvatsku, redovito provode za topografske svrhe (Straub i dr. 2013). Fotogrametrijskim procesiranjem aerosnimaka nastaje oblak točaka koji je vrlo sličan oblaku točaka dobivenom iz prvog povrata zračnim laserskim skeniranjem (Pitt i dr. 2015). Kao i kod ALS tehnologije, daljnjim procesiranjem oblaka točaka izrađuje se DMPK, a koji se u kombinaciji s DMR-om koristi za izradu DMVK-a.

Ukoliko se radi o gustim sklopljenim sastojinama, na aerosnimkama nije vidljivo tlo, te stoga nije moguće izraditi DMR zadovoljavajuće točnosti, i to poglavito u šumskim područjima s većim nagibima terena. Stoga je za šumska područja kompleksnijih sastojinskih i stanišnih karakteristika uputno koristiti postojeći DMR (Rahlfi dr. 2017). Primjerice, u mnogim zemljama Europe već postoji dostupan nacionalni DMR izrađen iz ALS podataka. Iako je u planu, u Hrvatskoj još uvijek nije provedeno nacionalno ALS prikupljanje podataka, već takvi podaci postoje za određena manja područja koja su skenirana s posebnim ciljem (Ba- lenović i dr. 2018). Trenutno je u Hrvatskoj službeno dostupan nacionalni DMR izrađen fotogrametrijskim procesiranjem aerosnimaka te dodatnim terenskim prikupljanjem podataka i vektorizacijom postojećih topografskih karata. U okviru komparativnih studija (Balenović i dr. 2018, 2019) gdje je ispitana i uspoređena točnost ALS DMR-a i postojećeg službenog nacionalnog (tzv. fotogrametrijskog) DMRa, utvrđeno je su da se u nedostatku ALS DMR-a postojeći nacionalni DMR može koristiti u nizinskim šumskim područjima Republike Hrvatske kao podloga za procjenu strukturnih elemenata šumskih sastojina. Također, Balenović i dr. $(2018,2019)$ su istaknuli da je u svakom slučaju neophodna i prethodna kontrola DMR-a. Naime, utvrđeno je da su u skupu vektorskih podataka DMR-a moguće grube pogreške, koje mogu značajno utjecati na točnost samog DMR-a te posljedično i na točnost procjene strukturnih elemenata šumskih sastojina. Takve pogreške su rijetke, ali i lako uočljive.

3D oblak točaka, ali i DMVK, omogućuju dobivanje raznovrsnih metričkih podataka (npr. visinski podaci, podaci gustoće krošanja) i karakterizaciju vertikalne strukture šumskih sastojina, a u kombinaciji s referentnim terenskim podacima te izrađenim modelima i procjenu strukturnih elemenata šumskih sastojina (npr. visina, temeljnica, drvna zaliha, biomasa) (White i dr. 2013). Općenito, postoje dva glavna pristupa za dobivanje informacija o šumama iz oblaka točaka ili DMVK-a: pristup temeljen na površini (ABA - prema engl. area-based approach) i pristup temeljen na pojedinačnom stablu (ITBA - prema engl. individual tree-based approach) (White i dr. 2013, Rahlf i dr. 2015). ABA pristup koristi metričke podatke iz oblaka točaka za niz ploha kao ulaz (nezavisne varijable ili prediktori) u statistički model za procjenu šumskih varijabli (zavisne varijable). Čitavo područje od interesa (npr. gospodarska jedinica) se potom podijeli na pravilne kvadrate (npr. 20x20 m) čija površina približno odgovara površini ploha korištenih za izradu modela (npr. $400 \mathrm{~m}^{2}$ ). Za svaki kvadrat se potom izračunaju odabrane nezavisne varijable (metrički podaci) te se na temelju izrađenih modela procjenjuju sastojinske varijable unutar svakog pojedinog kvadrata, i to na cijelom području od interesa (tzv. 'wall-to wall' mapiranje strukturnih elemenata šumskih sastojina) (White i dr. 2013). Za navedeni ABA pristup postoje programska rješenja, poput FUSION LDV softvera (McGaughey 2018), koja uvelike automatiziraju cjelokupni postupak. Kod ITBA pristupa prvi korak je segmentacija pojedinačnog stabla, a zatim određivanje visine stabla i određene dimenzije krošnja (promjera, površine) koja se potom mogu koristiti za izračun ostalih varijabli stabala (npr. prsni promjer, temeljnica, volumen, biomasa, itd.). Za razliku od ABA pristupa, ITBA pristup još uvijek nije našao operativnu primjenu i to uglavnom zbog teškoća pri segmentaciji pojedinačnih stabala, a koja su posebno izra- 
žena u šumama kompleksnijih strukturnih karakteristika (Holopainen i dr. 2014, White i dr. 2016).

Mogućnost primjene digitalne fotogrametrije, odnosno aerosnimaka u izmjeri šuma, nalazi se u fokusu brojnih istraživanja tijekom proteklih 10-ak godina, a detaljan pregled provedenih istraživanja prikazali su White i dr. (2016) i Goodbody i dr. (2019). Rezultati procjene strukturnih varijabli su najčešće evaluirani na razini plohe, a tek u manjem broju istraživanja i na razini sastojine odnosno odsjeka (Bohlin i dr. 2012, Rahlf i dr. 2014, Gobakken i dr. 2015, Pitt i dr. 2015, Stepper i dr. 2015, Puliti i dr. 2016, Iqbal i dr. 2019). U svim navedenim istraživanjima istaknut je velik potencijal digitalne aerofotogrametrije (DAP, prema engl. digital aerial photogrammetry) uz naglasak na njenu financijsku isplativost $\mathrm{u}$ usporedbi s ALS tehnologijom, ali i klasičnim terenskim mjerenjima. Iako oblaci točaka ili DMVK dobiveni iz aerosnimaka i DAP pružaju znatno slabiju karakterizaciju vertikalne strukture šumskih sastojina nego što to daje ALS tehnologija, navedena istraživanja ukazuju tek na neznatne razlike između dviju tehnologija (DAP i ALS) pri procjeni strukturnih varijabli šumskih sastojina.

Budući da je u većini dosadašnjih istraživanja temeljenim na ABA pristupu evaluirana točnost procjene strukturnih varijabli na razini plohe, a u znatnoj manjoj mjeri na razini sastojine (odsjeka), Balenović i dr. (2017) razvili su fotogrametrijsku metodu procjene strukturnih elemenata šumskih sastojina na razini sastojine (SBA, prema engl. stand-based approach). SBA metoda odnosno pristup, temeljen je na postojećim fotogrametrijskim materijalima (aerosnimke iz topografskih nacionalnih snimanja, službeni DMR) te podacima postojećih šumskogospodarskih planova. Osnovni preduvjet za primjenu SBA je približno vremensko poklapanje aerosnimanja te terenskog prikupljanja podataka korištenog šumskogospodarskog plana.

Kao i kod klasičnog ABA pristupa, i kod SBA pristupa je prvotno potrebno izraditi modele (jednadžbe) za procjenu strukturnih elemenata sastojina. Međutim, u ovom slučaju, modeli se izrađuje na određenom broju odsjeka sličnih strukturnih karakteristika (npr. uređajni razred), gdje se kao nezavisne varijable koriste metrički podaci čitavih odsjeka dobiveni iz aerosnimaka, a kao zavisne varijable se koriste podaci iz šumskogospodarskih planova. Za razliku od klasičnog ABA pristupa, SBA ne zahtijeva dodatna terenska mjerenja za uspostavu modela, te stoga predstavlja brz, jednostavan i ekonomičan način procjene strukturnih elemenata šumskih sastojina. Nadalje, pretpostavka je da se tako izrađeni modeli mogu koristiti i u drugim šumskim predjelima te sastojinama sličnih karakteristika. Stoga ovaj rad predstavlja nastavak prethodnog istraživanja (Balenović i dr. 2017) te ima za cilj dodatno istražiti i evaluirati učinkovitost $i$ točnost SBA pristupa i razvijene fotogrametrijske metode za procjenu strukturnih elemenata sastojina. Konkretno, u ovom radu će se na području šuma hrasta lužnjaka Pokupskog bazena testirati mogućnost korištenja SBA metode, kao i postojećih fotogrametrijskih modela procjene sastojinskog volumena izrađenih za šume hrasta lužnjaka Spačvanskog bazena.

\section{MATERIJAL I METODE MATERIAL AND METHODS}

\section{Područje istraživanja i referentni terenski podaci - Study area and field reference data}

Istraživanje je provedeno na području nizinskih šuma hrasta lužnjaka gospodarske jedinice Jastrebarski lugovi (Uprava šuma Podružnica Karlovac) smještene u središnjem dijelu Hrvatske, u neposrednoj blizini Jastrebarskog. Gospodarska jedinica čini sastavni dio šumskog kompleksa Pokupski bazen. Istraživanjem je obuhvaćeno 87 odsjeka uređajnog razreda hrasta lužnjaka starosti od 30 do 170 godina ukupne površine 1257,48 ha (slika 1). Jednodobne sastojine hrasta lužnjaka (Quercus robur L.) na odabranom području uglavnom su mješovite, gdje su uz hrast lužnjak od ostalih vrsta drveća u značajnoj mjeri prisutni obični grab (Carpinus betulus L.), poljski jasen (Fraxinus angustifolia L.) i crna joha (Alnus glutinosa Gaertn.). Sastojine su uglavnom na II. i III. bonitetu staništa, dok se tek 7 odabranih sastojina nalazi na I. bonitetu staništa. Strukturne karakteristike odabranih sastojina na području istraživanja prikazane su u tablici 1. Nadmorska visina odabranog područja kreće se u rasponu od 105 do $121 \mathrm{~m}$. Tla su hidromorfna, pretežno ravničarski pseudoglej (Mayer 1966), a prema Svjetskoj referentnoj osnovici za tlo (WRB 2006) klasificirana su kao luvični stagnozol. Klima je umjereno topla sa srednjom godišnjom temperaturom $10,6^{\circ} \mathrm{C}$ i padalinama od $962 \mathrm{~mm}$ godišnje (podaci Državnog hidrometeorološkog zavoda za najbližu meteorološku postaju za razdoblje 1981.-2010.).

Kao referentni podaci za validaciju fotogrametrijski procijenjenog volumena korišteni su podaci o volumenu sastojina (volumen krupnog drva iznad $7 \mathrm{~cm}$ ) iz važeće Osnove gospodarenja (2014.-2023.). Budući da je između vremena izrade Osnove gospodarenja odnosno terenskog prikupljanja podataka i vremena aerosnimanja postojao vremenski razmak od oko 1,5 godine, volumenu svake sastojine pridodan je 1,5 tečajni godišnji prirast iskazan u Osnovi. Također, kao referentne sastojine odabrane su samo one u kojima nije bilo značajnih sječa u vremenskom razdoblju od početka važenja Osnove gospodarenja (početak 2014. g.) do aerosnimanja (ljeto 2015. g.).

\section{Fotogrametrijski materijal - Photogrammetric material}

Fotogrametrijski materijal korišten u radu nabavljen je od Državne geodetske uprave (DGU), a sastojao se od aerosnimaka te trodimenzionalnih (3D) vektorskih podataka terena. 


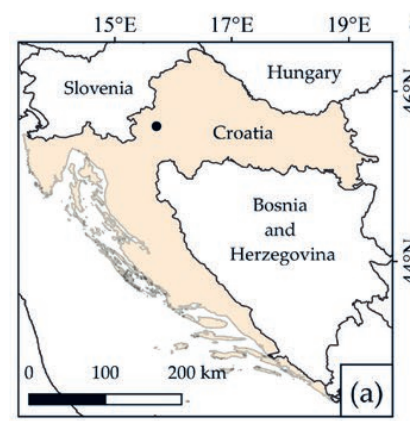

Legenda / Legend

- Gruba lokacija / approximate location Odsjeci / stands

Odabrani odsjeci / selected stands

Projekcija: HTRS96/TM EPSG : 3765

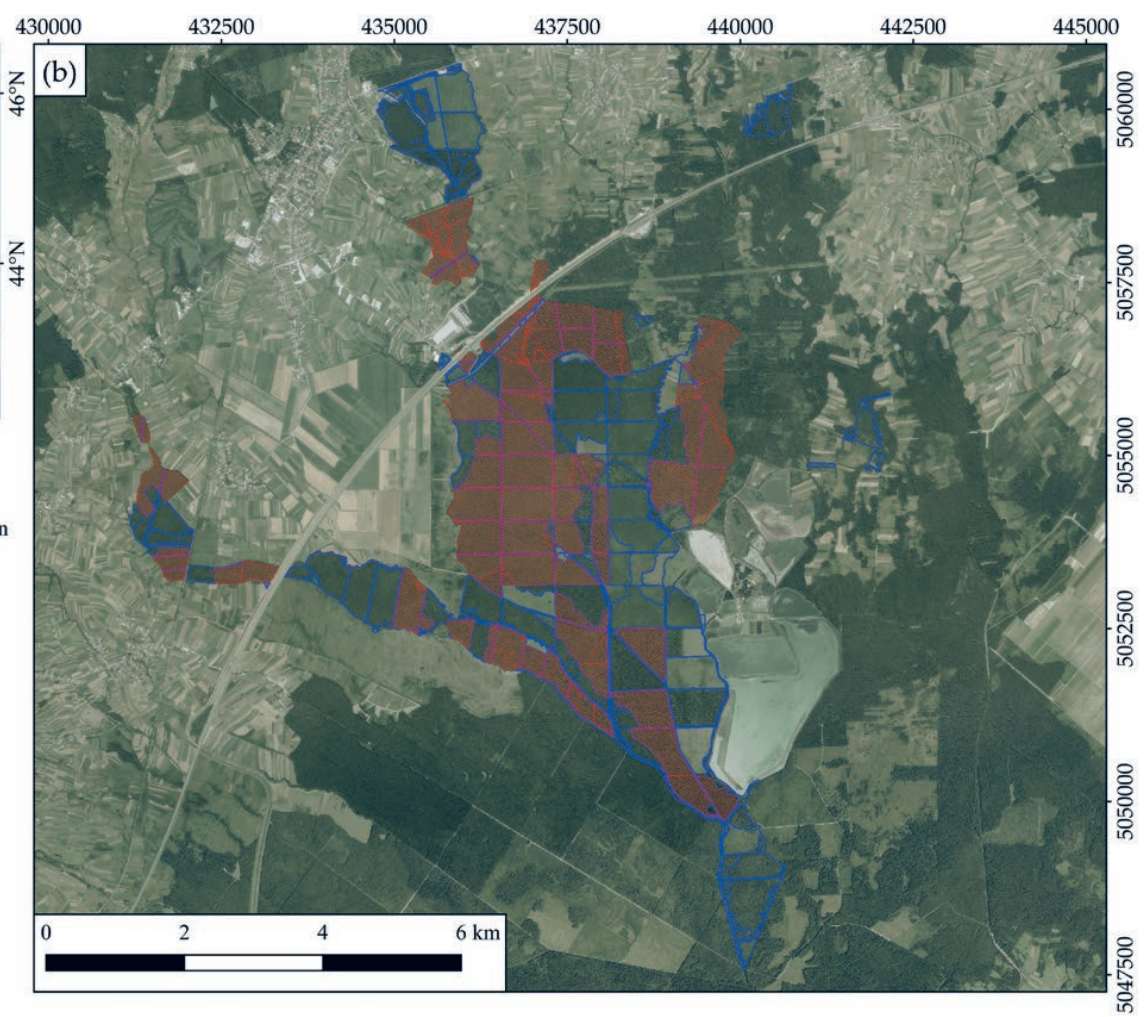

Slika 1. Položaj gospodarske jedinice Jastrebarski lugovi (a). Područje istraživanja s prostornim rasporedom odabranih sastojina (b).

Figure 1 Geographic location of the management unit Jastrebarski lugovi (a). Study area with the spatial distribution of selected forest stands (b).

Tablica 1. Deskriptivna statistika osnovnih strukturnih elemenata za 87 odabranih referentnih jednodobnih sastojina hrasta lužnjaka (podaci su dobiveni iz Osnove gospodarenja i odnose na početak 2014.g.).

Table 1 Descriptive statistics of the stand-level forest attributes for 87 selected even-aged pedunculate oak stands (data were obtained from the Forest management plan and present the state at the beginning of the 2014).

\begin{tabular}{|c|c|c|c|c|}
\hline $\begin{array}{l}\text { Strukturni element } \\
\text { Forest attribute }\end{array}$ & $\begin{array}{l}\text { Minimum } \\
\text { Minimum }\end{array}$ & $\begin{array}{l}\text { Maksimum } \\
\text { Maximum }\end{array}$ & $\begin{array}{c}\text { Srednja } \\
\text { vrijednost } \\
\text { Mean }\end{array}$ & $\begin{array}{c}\text { Standardna } \\
\text { devijacija } \\
\text { Standard } \\
\text { deviation }\end{array}$ \\
\hline $\begin{array}{l}\text { Starost (godine) } \\
\text { Age (years) }\end{array}$ & 30,0 & 170,0 & 94,5 & 41,9 \\
\hline $\begin{array}{l}\text { Srednji promjer }(\mathrm{cm}) \\
\text { Mean } \mathrm{dbh}(\mathrm{cm})\end{array}$ & 15,5 & 59,5 & 35,7 & 11,8 \\
\hline $\begin{array}{l}\text { Srednja visina }(\mathrm{m}) \\
\text { Mean height }(\mathrm{m})\end{array}$ & 14,4 & 30,7 & 23,3 & 4,4 \\
\hline $\begin{array}{l}\text { Broj stabala (stabala } \cdot \mathrm{ha}^{-1} \text { ) } \\
\text { Stand density (trees } \cdot \mathrm{ha}^{-1} \text { ) }\end{array}$ & 117,0 & 982,0 & 425,0 & 174,3 \\
\hline $\begin{array}{l}\text { Temeljnica }\left(\mathrm{m}^{2} \cdot \mathrm{ha}^{-1}\right) \\
\text { Basal area }\left(\mathrm{m}^{2} \cdot \mathrm{ha}^{-1}\right)\end{array}$ & 15,1 & 40,0 & 26,0 & 4,9 \\
\hline $\begin{array}{l}\text { Volume }\left(\mathrm{m}^{3} \cdot h \mathrm{a}^{-1}\right) \\
\text { Volume }\left(m^{3} \cdot h \mathrm{a}^{-1}\right)\end{array}$ & 106,0 & 574,2 & 311,5 & 106,5 \\
\hline
\end{tabular}

Aerosnimke su prikupljene tijekom vegetacijskog razdoblja 2015. g. u okviru regularnog topografskog aerosnimanja Republike Hrvatske. Snimanje je obavljeno s UltraCam Xp digitalnom fotogrametrijskom kamerom velikog formata (Gruber i Wiechert, 2009). Područje istraživanja pokriveno je s ukupno 84 aerosnimke prostorne rezolucije $\approx 0,30 \mathrm{~m}$
(GSD - prema engl. Ground Sample Distance) snimljenih u sedam nizova s uzdužnim preklopom (u smjeru leta zrakoplova) od $60 \%$ i poprečnim (bočnim) preklopom od $30 \%$. Radiometrijska rezolucija aerosnimaka iznosila je 24 bita, dok je veličina aerosnimaka iznosila $17.310 \times 11.310$ piksela za pankromatski kanal te $5.770 \times 3.770$ piksela za multispektralne kanale, a veličina piksela svih kanala bila je $6 \mu \mathrm{m}$. Isporučene snimke su bile pred-procesirane prema specifikacijama proizvoda DGU, što je uključivalo provedenu aerotriangulaciju (izjednačenje bloka aerosnimaka) te radiometrijsku i geometrijsku korekciju. Zajedno s pred-procesiranim aerosnimkama, dostavljeni su i parametri unutarnje (kalibracija kamere) te vanjske (koordinate projekcijskih središta snimaka i kutovi rotacije u trenutku snimanja) orijentacije potrebni za daljnje fotogrametrijsko procesiranje.

Isporučeni 3D vektorski podaci terena sastojali su se od linijskih i točkastih podataka. Linijski podaci obuhvaćaju lomne linije terena (prijelomnice) i linije oblika, dok točkasti podaci obuhvaćaju markantne točke terena i pravokutnu mrežu visinskih točaka. Vektorski podaci terena prikupljeni su uglavnom stereo fotogrametrijskom izmjerom aerosnimaka, a u manjoj mjeri terenskim prikupljanjem podataka te vektorizacijom postojećih karata. Na području istraživanja prosječni broj točaka u linijskim objektima iznosio je 492 točaka $\mathrm{km}^{-2}$, dok je prosječni broj točkastih objekata 
iznosio 141 točaka $\cdot \mathrm{km}^{-2}$. U nedostatku podataka dobivenih zračnim laserskim skeniranjem, navedeni podaci predstavljaju službene podatke za izradu DMR-a. Detaljan opis 3D vektorskih podataka dan je u radu Balenović i dr. (2018).

\section{Fotogrametrijsko procesiranje - Photogrammetric processing}

Fotogrametrijsko procesiranje sastojalo se od izrade DMR-a, DMPK-a i DMVK-a.

Za izradu DMR-a korišteni su 3D vektorski podaci terena. Vertikalna točnost istih vektorskih podataka te izrađenog DMR-a prostorne rezolucije $5 \mathrm{~m}$, ali na manjem području g.j. Jastrebarskih lugovi testirana je u radu Balenović i dr. (2018). U usporedbi s 22 kontrolne točke, precizno izmjerene GNSS (prema engl. Global Navigation Satellite System) uređajem povezanim s CROPOS (prema engl. CROatian POSitioning System) VPPS (visokoprecizni servis pozicioniranja u realnom vremenu) sustavom, za izrađeni DMR dobiven je korijen srednje kvadratne pogreške od $0,35 \mathrm{~m}$, srednja pogreška od $0,17 \mathrm{~m}$ te standardna devijacija od 0,31 m. Nadalje, Balenović i dr. (2018) ustanovili su postojanje određenog broja grubih pogrešaka u samim 3D vektorskim podacima koje mogu značajno utjecati na vertikalnu točnost izrađenog DMR-a. Stoga je prije same izrade DMR-a provedena detekcija i eliminacija grubih pogrešaka iz 3D vektorskih podataka u Grass GIS programskom paketu, a prema metodi opisanoj u radu Gašparović i dr. (2018). Ukupno je detektirana 91 gruba pogreška, te je iz tako 'pročišćenih' 3D vektorskih podataka najprije izrađena nepravilna mreža trokuta (TIN, prema engl. triangulated irregular network) koja je potom linearnom interpolacijom prevedena u rasterski DMR prostorne rezolucije, odnosno veličine piksela $5 \times 5 \mathrm{~m}$. DMR je izrađen korištenjem Global Mapper 19.1 (Blue Marble Geographics, Hallowell, Maine, $\mathrm{SAD}$ ) računalnog programa za obradu prostornih podataka.

Za izradu DMPK-a korištene su aerosnimke te parametri vanjske i unutarnje orijentacije, a cjelokupni postupak proveden je u digitalnom fotogrametrijskom sustavu PHOTOMOD 6.3 (Racurs Co., Moskva, Rusija). Ponajprije na temelju parametara unutarnje i vanjske orijentacije dobivenih iz DGU, provedena je a priori unutarnja i vanjska orijentacija aerosnimaka. Nakon toga, izjednačenje bloka aerosnimaka provedeno je metodom zrakovnog snopa, pritom određivajući samo rotacijske parametre vanjske orijentacije, dok su unutarnja orijentacija i pozicije snimaka uzete kao fiksne. Zatim je metodom slikovne korelacije, i to korištenjem Dense DSM algoritma u sklopu PHOTOMOD sustava izrađen rasterski DMPK prostorne rezolucije $5 \mathrm{~m}$.

Preklapanjem DMR-a i DMPK-a, odnosno oduzimanjem DMR-a od DMPK-a izrađen je rasterski DMVK-a prostorne rezolucije $5 \mathrm{~m}$ (Slika 2), također u PHOTOMOD sustavu. Iako korištene aerosnimke pružaju mogućnost izrade DMVK-a vrlo visoke prostorne rezolucije (npr. 0,3 $\mathrm{m}$ ), za potrebe ovoga rada izrađen je DMVK znatno niže rezolucije u svrhu konzistentnog nastavka istraživanja (Balenović i dr. 2017). Osim toga, u istom istraživanju je ispitan utjecaj prostorne rezolucije DMVK-a na točnost procjene volumena sastojine, te su utvrđene tek neznatne razlike između fotogrametrijski procijenjenih volumena korištenjem DMVK-a prostorne rezolucije $1 \mathrm{~m}, 2 \mathrm{~m}$, i 5m. Također, DMVK niže prostorne rezolucije sadrži znatno manje prostornih podataka, što značajno ubrzava i olakšava fotogrametrijsko procesiranje te pridobivanje metričkih po-

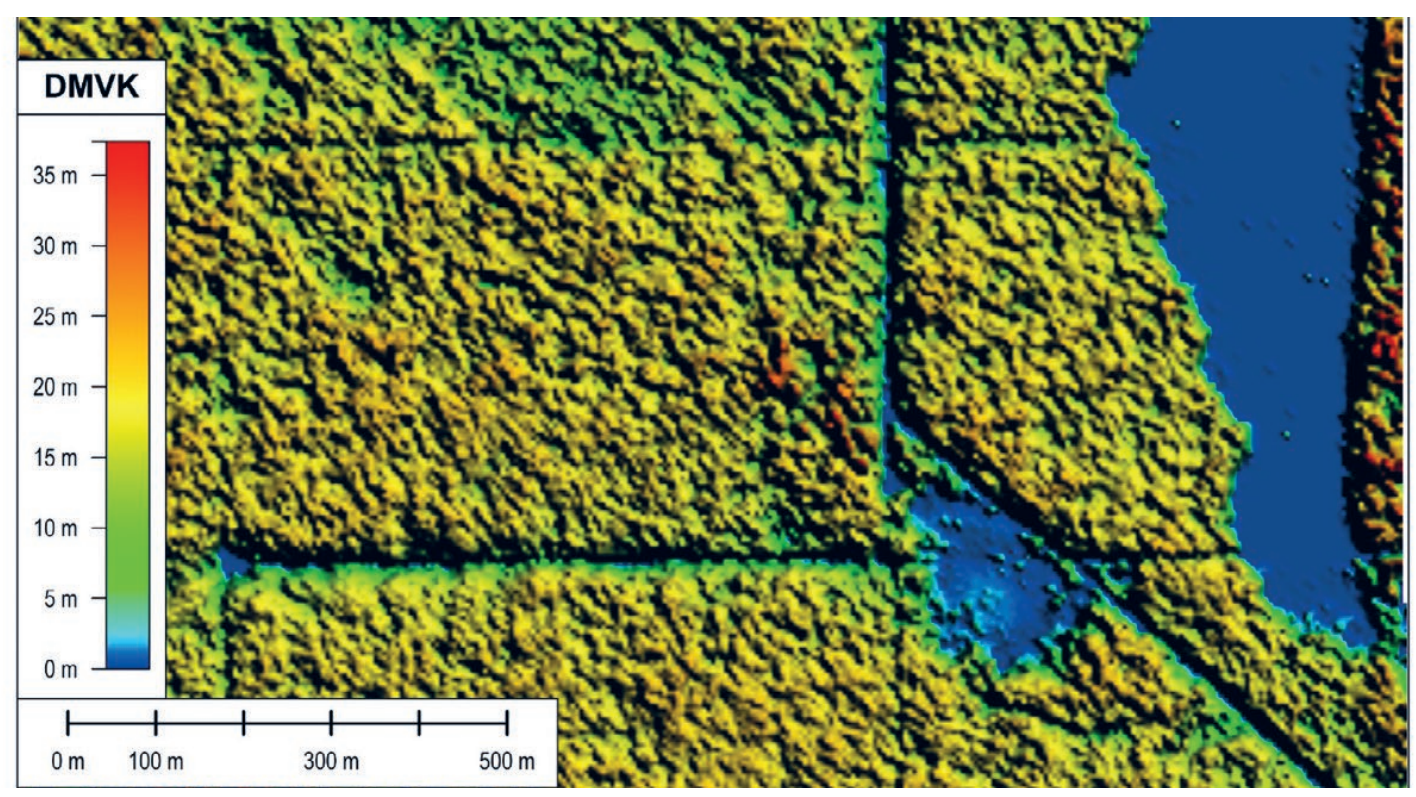

Slika 2. Prikaz rasterskog digitalnog modela visine krošanja (DMVK-a) na dijelu gospodarske jedinice Jastrebarski lugovi.

Figure 2 An example of raster Canopy Height Model (CHM) on the part of the management unit Jastrebarski lugovi. 
dataka, posebice ako se radi o većim površinama poput predmetne gospodarske jedinice.

Svi pikseli rasterskog DMVK-a s visinskim vrijednostima većim od $45 \mathrm{~m}$ smatrani su kao grube pogreške fotogrametrijskog procesiranja (slikovne korelacije) te su filtriranjem izostavljeni (izbrisani) iz DMVK-a. Gornja granica od 45 $m$ je definirana na temelju maksimalnim mogućih visina stabala na području istraživanja. Nadalje, po uzoru na druga slična istraživanja (Stepper i dr. 2015, Puliti i dr. 2016, Balenović i dr. 2017), svi pikseli s visinskim vrijednostima manjima od $5 \mathrm{~m}$ također su filtriranjem izostavljeni iz DMVKa. Na taj način izostavljeni su oni pikseli rastera koji opisuju prizemnu vegetaciju, grmlje i manja stabla s prsnim promjerom $<10 \mathrm{~cm}$. Naime, na području istraživanja sva stabla $s$ prsnim promjerom $\geq 10 \mathrm{~cm}$ imaju visine $>5 \mathrm{~m}$.

\section{Izračun metričkih podataka (varijabli) iz DMVK-a za} fotogrametrijsku procjenu volumena sastojina - CHM metrics extraction for photogrammetric stand volume estimation

Rasterski DMVK te gospodarska podjela g.j. Jastrebarski lugovi u vektorskom obliku učitani su u Global Mapper računalni program. Preklapanjem navedenih vektorskih slojeva i rasterskog DMVK-a za svaki odabrani odsjek dobivene su položajne $(\mathrm{x}, \mathrm{y})$ i visinske $(\mathrm{z})$ vrijednosti (koordinate) svih piksela u .csv formatu. Na temelju navedenih vrijednosti, za svaki odsjek izračunate su varijable (Tablica 2) koje su se dalje koristile kao prediktori (nezavisne varijable) u modelima za procjenu volumena sastojina (Balenović i dr. 2017).

\section{Fotogrametrijska procjena volumena sastojina - Photogrammetric stand-level volume estimation}

Za fotogrametrijsku procjenu volumena sastojina na području nizinskih šuma hrasta lužnjaka Pokupskog bazena korišteni su postojeći modeli izrađeni za područje nizinskih šuma hrasta lužnjaka Spačvanskog bazena (Balenović i dr. 2017). Balenović i dr. (2017) izradili su višestruke log-linearne regresijske modele za različite prostorne rezolucije DMVK-a (1 m, 2 m, i 5 m), i to na uzorku od 274 sastojine (odsjeka) starosti iznad 30 godina, te su ih evaluirali na ne- ovisnom uzorku od također 274 sastojine. U ovom radu su korišteni isključivo modeli za fotogrametrijsku procjenu volumena sastojina iz DMVK-a prostorne rezolucije $5 \mathrm{~m}$. Za prvi model (jednadžba 1), kao nezavisne varijable korišteni su isključivo podaci dobiveni iz DMVK-a prostorne rezolucije $5 \mathrm{~m}$, dok je za drugi model (jednadžba 2) podacima iz DMVK-a pridodana i starost sastojine (ST) preuzeta iz važeće Osnove gospodarenja.

$$
\begin{aligned}
& \ln \left(V_{m}\right)=\beta_{0}+\beta_{1} \cdot h_{\max }+\beta_{2} \cdot p_{30}+\beta_{3} \cdot p_{90}+\beta_{4} \cdot C C_{30} \\
& \ln \left(V_{m}\right)=\beta_{0}+\beta_{1} \cdot h_{\max }+\beta_{2} \cdot p_{25}+\beta_{3} \cdot p_{90}+\beta_{4} \cdot C C_{30}+\beta_{5} \cdot S A
\end{aligned}
$$

gdje je: $V_{m}$ - fotogrametrijski procijenjen volumen sastojine odnosno odsjeka $\left(\mathrm{m}^{3} \cdot \mathrm{ha}^{-1}\right), \beta_{0}$ - regresijska konstanta, $\beta_{1}$, $\beta_{2}, \beta_{3}, \beta_{4}, \beta_{5}$ - regresijski koeficijenti, $p_{25}, p_{30}, p_{90}-25$., 30 . i 90. visinski percentili, $C_{30}$ - sklop krošanja na visini od $30 \mathrm{~m}, \mathrm{SA}$ - starost sastojine.

Za procjenu volumena korišteni su parametri (regresijska konstanta i regresijski koeficijenti) postojećih modela izrađenih za područje Spačvanskog bazena, ali su izrađeni parametri i za područje Pokupskog bazena u programskom paketu STATISTICA 11 (Hill i Levicki 2007), i to na uzorku od 58 odsjeka. Kako bi se izbjegla pristranost pri odabiru uzorka za parametrizaciju modela, sastojine su poredane prema starosti od najmlađih do najstarijih. Nakon toga, svaka treća sastojina je odabrana u uzorak za validaciju. $\mathrm{Na}$ taj način $2 / 3$, odnosno 58 sastojina korišteno je za parametrizaciju modela, dok je 1/3, odnosno 29 sastojina korišsteno za validaciju. Naposljetku, volumen sastojine je procijenjen na temelju 4 modela (Tablica 3).

Kako bi se tijekom transformacije iz logoritamskih u linearne vrijednosti volumena sastojine uvažila eventualna pristranost, za svaki je model izračunat korekcijski faktor $(k)$ prema Snowdonu (1991) (jednadžba 3), i to kao odnos aritmetički srednje vrijednosti volumena sastojina dobivenih iz Osnove gospodarenja za čitavi promatrani uzorak $(\bar{V})$, te aritmetički srednje vrijednosti fotogrametrijski procijenjenih volumena sastojina za čitavi promatrani uzorak $\left(\bar{V}_{m}\right)$. Naposljetku, korigirani fotogrametrijski volumen $\left(V^{\prime}\right)$ za svaku sastojinu (odsjek) izračunat je množenjem fotogra-

Tablica 2. Nezavisne varijable (prediktori) izračunati iz DMVK za svaki pojedinačni odsjek te korišteni za procjenu volumena sastojine. Table 2 Independent variables (predictors) extracted from CHM for each stand and used for stand-level volume estimation.

\begin{tabular}{cl}
$\begin{array}{c}\text { DMIVK varijabla } \\
\text { CHM metric }\end{array}$ & \multicolumn{1}{c}{$\begin{array}{c}\text { Opis } \\
\text { Description }\end{array}$} \\
\hline $\mathrm{h}_{\max }$ & $\begin{array}{l}\text { Maksimalna visina piksela u određenom odsjeku } \\
\text { Maximum height of pixels for the observed stand }\end{array}$ \\
$\mathrm{p}_{25,} \mathrm{p}_{30,}, \mathrm{p}_{90}$ & $\begin{array}{l}\text { 25., } 30 \text {. i } 90 \text {. visinski percentili izračunati na temelju visinskih vrijednosti odnosno z koordinata svih piksela određenog odsjeka } \\
25^{\text {th }}, 30^{\text {th }} \text {, and } 90^{\text {th }} \text { height percentiles calculated using height values (z coordinate) of each pixel in the observed stand }\end{array}$ \\
$\mathrm{CC}_{30}$ & Sklop krošanja na visini od $30 \mathrm{~m}$ - odnos između površine krošanja (piksela) na visini od $30 \mathrm{~m}$ i površine odsjeka \\
& Canopy cover at $30 \mathrm{~m}$ height - Ratio between canopy area (pixels) at $30 \mathrm{~m}$ height and stand area
\end{tabular}


Tablica 3. Opis modela korištenih za fotogrametrijsku procjenu volumena sastojina na području nizinskih šuma hrasta lužnjaka Pokupskog bazena. Table 3 Description of models used for photogrammetric estimation of stand volume in lowland pedunculate oak forests of Pokupsko basin.

\begin{tabular}{|c|c|c|}
\hline \multirow{2}{*}{$\begin{array}{l}\text { Model } \\
\text { Model }\end{array}$} & \multicolumn{2}{|c|}{$\begin{array}{c}\text { Opis } \\
\text { Description }\end{array}$} \\
\hline & $\begin{array}{l}\text { Nezavisne varijable } \\
\text { Independent variables }\end{array}$ & $\begin{array}{l}\text { Parametri (regresijska konstanta i koeficijenti) } \\
\text { Parameters (regression constant and coefficients) }\end{array}$ \\
\hline SB-1 & $\begin{array}{l}\text { DMVK varijable } \\
\text { CHM metrics }\end{array}$ & $\begin{array}{l}\text { Izvorni (izrađeni za područje Spačvanskog bazena) } \\
\text { Origin (developed for the Spačva basin area) }\end{array}$ \\
\hline SB-2 & $\begin{array}{l}\text { DMVK varijable, starost sastojine (SA) } \\
\text { CHM metrics, stand age (SA) }\end{array}$ & $\begin{array}{l}\text { Izvorni (izrađeni za područje Spačvanskog bazena) } \\
\text { Origin (developed for the Spačva basin area) }\end{array}$ \\
\hline PB-1 & $\begin{array}{l}\text { DMVK varijable } \\
\text { CHM metrics }\end{array}$ & $\begin{array}{l}\text { Novi (izrađeni za područje Pokupskog bazena) } \\
\text { New (developed for the Pokupsko basin area) }\end{array}$ \\
\hline PB-2 & $\begin{array}{l}\text { DMVK varijable, starost sastojine (SA) } \\
\text { CHM metrics, stand age (SA) }\end{array}$ & $\begin{array}{l}\text { Novi (izrađeni za područje Pokupskog bazena) } \\
\text { New (developed for the Pokupsko basin area) }\end{array}$ \\
\hline
\end{tabular}

metrijski procijenjenog volumena sastojine $(\mathrm{Vm})$ i korekcijskog faktora $(k)$ (jednadžba 4$)$.

$$
\begin{aligned}
k & =\frac{\bar{V}}{\bar{V}_{m}} \\
V^{\prime} & =V_{m} \cdot k
\end{aligned}
$$

\section{Validacija i ocjena točnosti - Validation and accuracy assessment}

Budući da su u modelima SB-1 i SB-2 korišteni izvorni parametri (regresijska konstanta i regresijski koeficijenti) izrađeni za područje Spačvanskog bazena, navedeni modeli su validirani na čitavom uzorku od 87 sastojina. Za parametrizaciju modela PB-1 i PB-2 korišteno je 2/3 uzorka odnosno 58 odsjeka. Stoga su PB-1 i PB-2 modeli validirani na preostaloj trećini uzorka od 29 odsjeka.

Za ocjenu točnosti fotogrametrijske procjene volumena sastojina u odnosu na volumen sastojine iz Osnove gospodarenja, za svaki model izračunato je srednje odstupanje (MD, prema engl. mean difference), te korijen srednje kvadratne pogreške (RMSE, prema engl. root mean square error). MD ukazuje na predznak odstupanja modelom procijenjenih vrijednosti, odnosno podcjenjuju li one ili precjenjuju referentne vrijednosti. Za MD se često koristi i termin pristranost (engl. bias), jer ukazuje na sistemsku pogrešku ko- rištenog modela procijenjenih vrijednosti. RMSE ukazuje na točnost fotogrametrijski procijenjenih vrijednosti u odnosu na referentne terenske vrijednosti. MD i RMSE izračunate su u mjernim jedinicama $\left(\mathrm{m}^{3} \cdot \mathrm{ha}^{-1}\right)$, te u postotnom iznosu od referentne vrijednosti prema jednadžbama 5-7:

$$
\begin{gathered}
M D=\frac{\sum_{i=1}^{n}\left(V_{i}^{\prime}-V_{i}\right)}{n} \\
M D_{\%}=\frac{M D}{\bar{V}} \cdot 100 \\
R M S E=\sqrt{\frac{\sum_{I=1}^{N}\left(V_{i}^{\prime}-V_{i}\right)^{2}}{n}} \\
\operatorname{RMSE}_{\%}=\frac{R M S E}{\bar{V}} \cdot 100
\end{gathered}
$$

gdje $V_{i}^{\prime}$ je fotogrametrijski procijenjen volumen za sastojinu (odsjek) $i, V_{i}$ je referentni volumen dobiven iz Osnove gospodarenja za sastojinu (odsjek) $i, n$ je broj sastojina (odsjeka).

\section{REZULTATI I DISKUSIJA

\begin{tabular}{|c|c|c|}
\hline $\begin{array}{l}\text { Model } \\
\text { Model }\end{array}$ & $\begin{array}{l}\text { Jednadžba } \\
\text { Equation }\end{array}$ & k \\
\hline SB-1 & $\ln \left(\boldsymbol{V}_{m}\right)=3,8901-0,0185 \cdot \boldsymbol{h}_{\max }+0,0161 \cdot \boldsymbol{p}_{30}+0,0818 \cdot \boldsymbol{p}_{90}-0,4090 \cdot \mathbf{C} \boldsymbol{C}_{30}$ & 1,0078 \\
\hline SB-2 & $\ln \left(\boldsymbol{V}_{\boldsymbol{m}}\right)=4,0780-0,0204 \cdot \boldsymbol{h}_{\max }+0,0175 \cdot \boldsymbol{p}_{25}+0,0672 \cdot \boldsymbol{p}_{90}-0,3315 \cdot \boldsymbol{C} \boldsymbol{C}_{30}+0,0026 \cdot \boldsymbol{S A}$ & 1,0074 \\
\hline PB-1 & $\operatorname{In}\left(\boldsymbol{V}_{m}\right)=3,8247-0,0111 \cdot \boldsymbol{h}_{\max }-0,0037 \cdot \boldsymbol{p}_{30}+0,0858 \cdot \boldsymbol{p}_{90}-0,2478 \cdot \boldsymbol{C} \boldsymbol{C}_{30}$ & 1,0124 \\
\hline PB-2 & $\ln \left(\boldsymbol{V}_{m}\right)=3,9908-0,0150 \cdot \boldsymbol{h}_{\max }+0,0003 \cdot \boldsymbol{p}_{25}+0,0768 \cdot \boldsymbol{p}_{90}-0,2216 \cdot \boldsymbol{C} \boldsymbol{C}_{30}+0,0013 \cdot \boldsymbol{S A}$ & 1,0120 \\
\hline
\end{tabular} RESULTS AND DISCUSSION}

Matematički izrazi log-linearnih regresijskih modela korištenih za fotogrametrijsku procjenu volumena sastojina na

Tablica 4. Modeli (jednadžbe) za fotogrametrijsku procjenu volumena sastojina s vrijednostima parametara i korekcijskog faktora (k). Table 4 Models (equations) used for photogrammetric estimation of stand volume with parameters and correction factor ( $k$ ) values. 
Tablica 5. Rezultati validacije fotogrametrijskih modela procjene volumena sastojina prikazanih i opisanih u Tablicama 3 i 4.

Table 5 Validation results for photogrammetric stand-level volume models described in Table 3 and 4.

\begin{tabular}{|c|c|c|c|c|c|}
\hline $\begin{array}{l}\text { Model } \\
\text { Model }\end{array}$ & $\mathbf{R}_{\text {adj }}^{2}$ & $\begin{array}{c}\text { MD } \\
\left(\mathrm{m}^{3} \cdot \mathrm{ha}^{-1}\right)\end{array}$ & $\begin{array}{c}\mathbf{M D}_{\%} \\
(\%)\end{array}$ & $\begin{array}{c}\text { RMSE } \\
\left(\mathrm{m}^{3} \cdot \mathrm{ha}^{-1}\right)\end{array}$ & $\begin{array}{c}\text { RMSE }_{\%} \\
(\%)\end{array}$ \\
\hline SB-1 & 0.75 & 27.01 & 8.41 & 59.31 & 18.47 \\
\hline SB-2 & 0.75 & 28.10 & 8.75 & 60.65 & 18.89 \\
\hline PB-1 & 0.86 & -14.17 & -4.49 & 37.95 & 12.03 \\
\hline PB-2 & 0.86 & -11.98 & -3.80 & 37.31 & 11.83 \\
\hline
\end{tabular}

području nizinskih šuma hrasta lužnjaka Pokupskog bazena prikazani su u tablici 4. Svi modeli, kao i procijenjeni parametri nezavisnih varijabli u svim modelima statistički su značajni ( $<0.001)$. U modelima SB-1 i PB-1 kao ulazne (nezavisne) varijable koristili su se isključivo podaci DMVK-a prostorne rezolucije $5 \mathrm{~m}$, dok je u modelima SB-2 i PB-2 pridodana i starost sastojine iz osnove gospodarenja.

Rezultati validacije fotogrametrijskih modela odnosno odstupanja fotogrametrijski procijenjenog volumena sastojina $\left(V^{\prime}\right)$ u odnosu na referentni volumen iz osnove gospodarenja $(V)$ prikazani su u tablici 5, dok je grafička analiza dobivenih rezultata prikazana na slici 3. Iz dobivenih rezultata vidljivo je značajno poboljšanje točnosti fotogrametrijske procjene volumena kod PB modela u odnosu na SB modele. Primjerice, kod međusobno usporedivih SB-1 i PB-1 modela, $\mathrm{R}_{\text {adj }}^{2}$ je kod PB-1 modela poboljšan za $11 \%, \mathrm{MD}_{\%} \mathrm{za}$ $3,92 \%$ u apsolutnoj vrijednosti, a RMSE ${ }_{\%}$ za značajnih 6,44\% u odnosu na SB-1 model. Vrlo slične vrijednosti dobivene su i za međusobno usporedive SB-2 i PB-2 modele. Prilog navedenome su i grafovi prikazani na slikama 3(a) i 3(b).

Uključivanje starosti sastojine, kao dodatne i lako pribavljive nezavisne varijable, nije značajno utjecalo na povećanje točnosti fotogrametrijske procjene volumena sastojina. Primjerice, dodavanjem starosti sastojine kod SB modela (SB-1 i SB-2), $\mathrm{R}_{\text {adj }}^{2}$ zadržao je istu vrijednost, dok su MD i $\mathrm{MD}_{\%}$ te RMSE i RMSE $\%$ vrijednosti čak neznatno pogoršane. Slično je dobiveno i za PB modele (SB-1 i SB-2) gdje je dodavanjem starosti sastojine $\mathrm{R}_{\text {adj }}^{2}$ kod oba modela zadržao istu vrijednost. Za razliku od SB modela, kod PB modela starost sastojine je poboljšala točnost procijene volumena sastojina, ali u neznatnim vrijednostima. $\mathrm{MD}_{\%}$ je poboljšan za $0.69 \%$, a $\mathrm{RMSE}_{\%}$ za $0,20 \%$. Isto je vidljivo iz grafičkog prikaza na slici 3(b) gdje su prikazana pojedinačna odstupanja u postotnim iznosima po odsjecima. Dodavanjem starosti u model, točnost procjene volumena je poboljšana u nekoliko pojedinačnih slučajeva. S obzirom da starost sastojine kao dodatna nezavisna varijabla ne utječe značajno na poboljšanje točnosti fotogrametrijske procjene volumena sastojina, SB-2 i PB-2 modeli nadalje neće biti predmet detaljnije rasprave.

Na prvi pogled SB i PB modeli pokazuju sličan trend (slika 3), tj. u sastojinama s manjim volumenom dolazi do precje- njivanja, dok u sastojinama s većim volumenom do podcjenjivanja stvarnih vrijednosti. Međutim, validacijski rezultati (tablica 5) ukazuju da fotogrametrijski procijenjeni volumeni sastojina korištenjem SB modela generalno precjenjuju stvarne (referentne) vrijednosti $\left(\mathrm{MD}_{\%} \approx 8,5 \%\right)$, dok su volumeni sastojina procijenjeni PB modelima podcijenjeni, ali u značajno manjoj mjeri $\left(\mathrm{MD}_{\%} \approx-4 \%\right)$. Iz slike 23(b) i prikazanih linija trendova vidljivo je da korištenjem SB modela dolazi do učestalog i značajnog precjenjivanja volumena u sastojinama s volumenom manjim od $\approx 300$ $\mathrm{m}^{3} \cdot \mathrm{ha}^{-1}$, dok se s porastom volumena sastojina precjenjivanje postupno smanjuje, te je u sastojinama s volumenom $\approx 400-450 \mathrm{~m}^{3} \cdot \mathrm{ha}^{-1}$ podjednako izraženo precjenjivanje i podcjenjivanje stvarnog volumena. U sastojinama s volumenom iznad $450 \mathrm{~m}^{3} \cdot \mathrm{ha}^{-1}$ dolazi do neznatnog precjenjivanja. Kod PB modela vidljiva je podjednaka raspodjela precijenjenih i podcijenjenih vrijednosti, te je uočljivo da tek jedna ili dvije veće pogreške podcjenjivanja dovode do zaključka da se volumen sastojine korištenjem PB modela generalno podcjenjuje $\left(\mathrm{MD}_{\%} \approx-4 \%\right.$, tablica 5$)$. Nadalje, vidljivo je da primjenom PB modela dolazi do precjenjivanja u sastojinama s volumenima do $\approx 220 \mathrm{~m}^{3} \cdot \mathrm{ha}^{-1}$, a u sastojinama s većim volumenima dolazi do podcjenjivanja u sličnim iznosima, uz tek dva izuzetka gdje iznosi podcjenjivanja prelaze $20 \%$ stvarnog (referentnog) volumena.

Za pretpostaviti je da su glavni razlog većem precjenjivanju volumena $\left(\mathrm{MD}_{\%} \approx 8,5 \%\right)$ korištenjem $\mathrm{SB}$ modela i manjem podcjenjivanju volumena $\left(\mathrm{MD}_{\%} \approx-4 \%\right)$ korištenjem $\mathrm{PB}$ modela strukturne i stanišne razlike između nizinskih šuma hrasta lužnjaka Spačvanskog bazena za koje su SB modeli i njihovi parametri izrađeni te nizinskih šuma Pokupskog bazena na kojima su isti modeli i primijenjeni. Korištenjem SB-1 modela volumen sastojina u Spačvanskom bazenu procijenjen je s pogreškom ( RMSE $_{\%}$ ) od 13,26\% (Balenović i dr. 2017), dok je primjenom istog modela u ovom istraživanju volumen sastojina u Pokupskom bazenu procijenjen s pogreškom od 18,47\%. Međutim, kako je već navedeno, dodatnom parametrizacijom modela dolazi do značajnog poboljšanja točnosti procjene sastojinskog volumena (tablica 5). Korištenjem PB-1 modela volumen sastojine procijenjen je s pogreškom od 12,03\%. Iz navedenog se može zaključiti da se model s pripadajućim nezavisnim varijablama $\left(\mathrm{h}_{\max }, \mathrm{p}_{30}, \mathrm{p}_{90} \mathrm{CC}_{30}\right)$ koji je izvorno izrađen na po- 

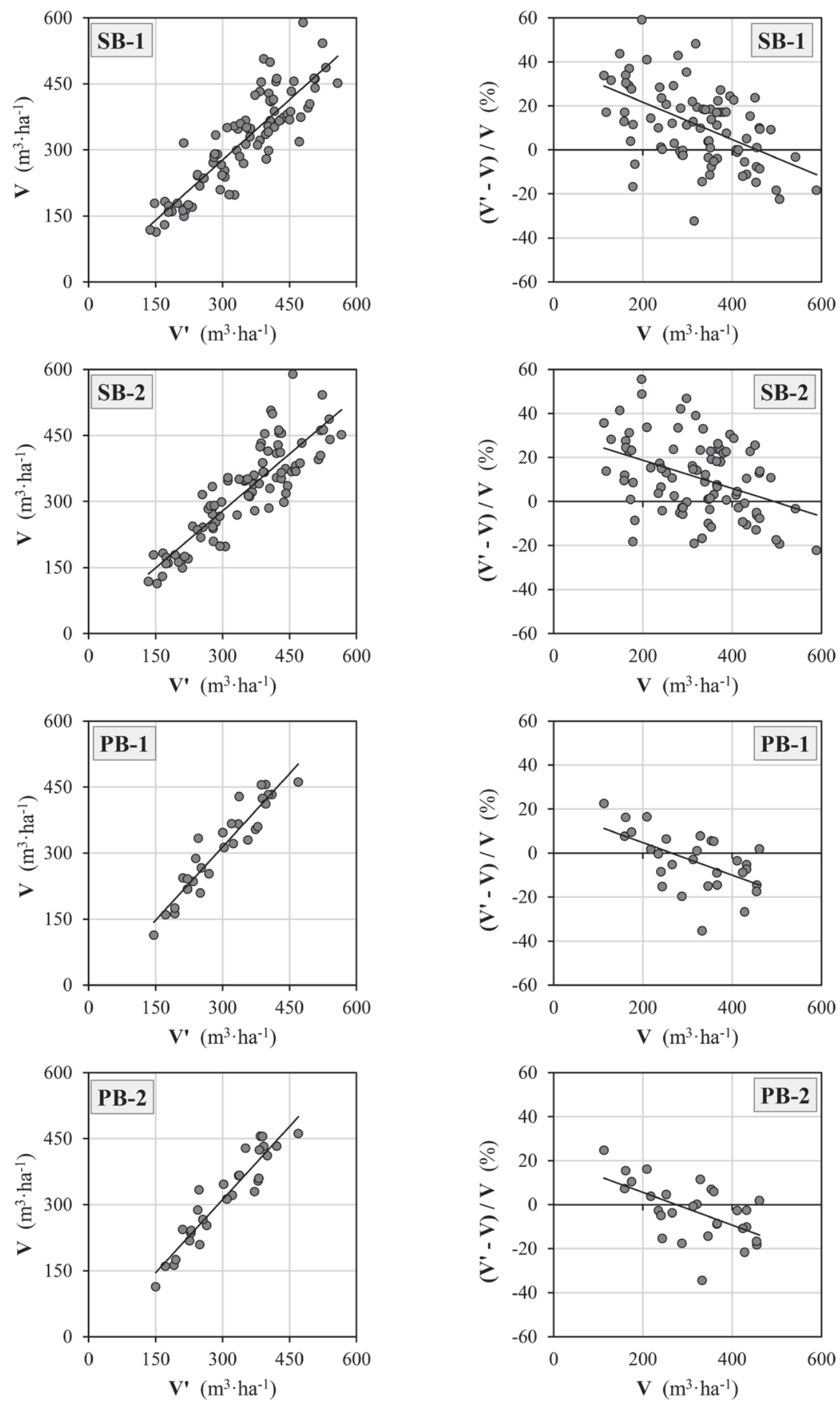

(a)

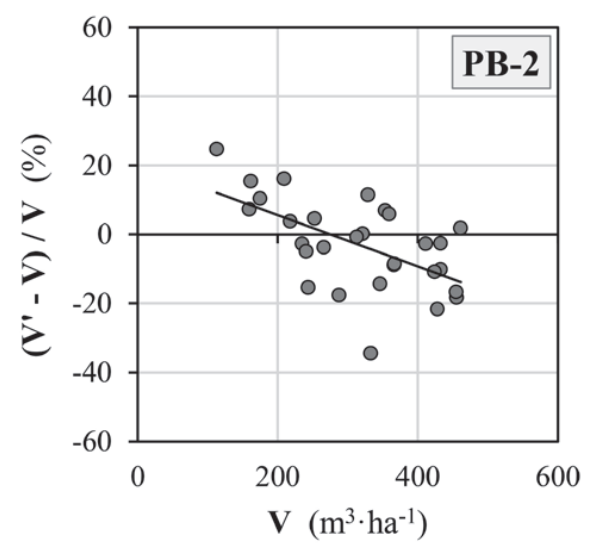

(b)

Slika 3. Grafička analiza: (a) Usporedba fotogrametrijski procijenjenog volumena sastojina (V') i referentnog volumena iz osnove gospodarenja (V), (b) Odstupanja fotogrametrijski procijenjenog volumena sastojina ((V'-V) $N$, \%) u odnosu na referentni volumen iz osnove gospodarenja (V). Figure 3 Graphycal analyses: (a) Comparison of photogrammetrically estimated stand volume ( $\left.V^{\prime}\right)$ and reference stand volume from management plan (V) (b) Deviations of photogrammetrically estimated stand volume $\left(\left(V^{\prime}-V\right) / N, \%\right)$ in relation to reference stand volume from management plan (V). 
Tablica 6. Opis i rezultati dosadašnjih istraživanja procjene volumena sastojinama primjenom aerosnimaka i digitalne fotogrametrije. Table 6 Desription and results of previous studies dealing with stand-level volume estimation using aerial images and digital photogrammetry.

\begin{tabular}{|c|c|c|c|c|c|}
\hline $\begin{array}{l}\text { Referenca } \\
\text { Referernce }\end{array}$ & $\begin{array}{l}\text { Lokacija } \\
\text { Location }\end{array}$ & $\begin{array}{l}\text { Tip šume } \\
\text { Forest type }\end{array}$ & $\begin{array}{l}\text { Glavne vrste drveća } \\
\text { Main tree species }\end{array}$ & $\begin{array}{l}\text { Teren } \\
\text { Terrain }\end{array}$ & $\begin{array}{l}\text { RMSE }_{\%} \\
(\%)\end{array}$ \\
\hline $\begin{array}{l}\text { Bohlin i dr. } \\
\text { (2012) }\end{array}$ & $\begin{array}{l}\text { J Švedska } \\
\text { S Sweden }\end{array}$ & $\begin{array}{l}\text { Borealna privatno gospodarena šuma } \\
\text { Boreal privately-owned managed forest }\end{array}$ & $\begin{array}{c}\text { Picea abies, Pinus sylvestris, } \\
\text { Betula spp. }\end{array}$ & $\begin{array}{l}\text { Relativno ravan } \\
\text { Relatively flat }\end{array}$ & $13,0-14,5$ \\
\hline $\begin{array}{l}\text { Rahlf i dr. } \\
\text { (2014) }\end{array}$ & $\begin{array}{l}\text { J Norveška } \\
\text { S Norway }\end{array}$ & $\begin{array}{l}\text { Borealna gospodarena šuma } \\
\text { Boreal managed forest }\end{array}$ & $\begin{array}{l}\text { P. abies, P. sylvestris, } \\
\text { Betula spp. }\end{array}$ & $\begin{array}{l}\text { Brdovit } \\
\text { Hilly }\end{array}$ & 18,1 \\
\hline $\begin{array}{l}\text { Gobakken i dr. } \\
\text { (2015) }\end{array}$ & $\begin{array}{l}\text { JI Norveška } \\
\text { SE Norway }\end{array}$ & $\begin{array}{l}\text { Borealna gospodarena šuma } \\
\text { Boreal managed forest }\end{array}$ & $\begin{array}{l}\text { P. abies, P. sylvestris, } \\
\text { Betula spp. }\end{array}$ & $\begin{array}{c}\text { Relativno ravan } \\
\text { Relatively flat }\end{array}$ & $13,1-17,4$ \\
\hline $\begin{array}{l}\text { Stepper i dr. } \\
\quad(2015)\end{array}$ & $\begin{array}{l}\text { J Njemačka } \\
\text { S Germany }\end{array}$ & $\begin{array}{l}\text { Mješovita, različitih strukturnih karakteristika } \\
\text { Mixed, various structural characteristics }\end{array}$ & $\begin{array}{c}\text { Fagus sylvatica, Quercus petraea, } \\
\text { P. sylvestris }\end{array}$ & $\begin{array}{l}\text { Razno } \\
\text { Various }\end{array}$ & $13,9-14,8$ \\
\hline $\begin{array}{l}\text { Puliti i dr. } \\
\text { (2016) }\end{array}$ & $\begin{array}{l}\text { JI Norveška } \\
\text { SE Norway }\end{array}$ & $\begin{array}{l}\text { Borealna gospodarena šuma } \\
\text { Boreal managed forest }\end{array}$ & $\begin{array}{l}\text { P. abies, P. sylvestris, } \\
\text { Betula spp. }\end{array}$ & $\begin{array}{l}\text { Relativno ravan } \\
\text { Relatively flat }\end{array}$ & $13,4-15,4$ \\
\hline $\begin{array}{l}\text { Balenović i dr. } \\
\qquad(2017)\end{array}$ & $\begin{array}{l}\text { I Hrvatska } \\
\text { E Croatia }\end{array}$ & $\begin{array}{l}\text { Nizinska šuma hrasta lužnjaka } \\
\text { Lowland pedunculate oak forest }\end{array}$ & $\begin{array}{l}\text { Q. robur, Fraxinus angustifolia, Alnus } \\
\text { glutinosa, Carpinus betulus }\end{array}$ & $\begin{array}{l}\text { Ravan } \\
\text { Flat }\end{array}$ & $12,6-13,6$ \\
\hline $\begin{array}{l}\text { Iqbal i dr. } \\
\text { (2019) }\end{array}$ & $\begin{array}{l}\text { NE Tasmania } \\
\text { (Australija) }\end{array}$ & $\begin{array}{l}\text { Plantaža ( } 10-30 \text { god.starosti) } \\
\text { Plantation ( } 10-30 \text { years-old) }\end{array}$ & $P$. radiata & $\begin{array}{l}\text { Valovit } \\
\text { Undulating }\end{array}$ & $9,9-41,4$ \\
\hline
\end{tabular}

dručju Spačvanskog bazena može koristiti i za procjenu volumena na području Pokupskog bazena te drugih područja, ali da je uputno izraditi lokalne parametre modela.

Dobiveni rezultati u skladu su s rezultatima dosadašnjih istraživanja (Bohlin i dr. 2012, Rahlf i dr. 2014, Gobakken i dr. 2015, Pitt i dr. 2015, Stepper i dr. 2015, Puliti i dr. 2016, Iqbal i dr. 2019) koja su se bavila procjenom volumena na razini sastojine (odsjeka) iz aerosnimaka. Usporedbom s rezultatima prikazanim u tablici 6 , vidljivo je da je u ovom istraživanju volumen procijenjen $s$ većom točnošću $\left(\mathrm{RMSE}_{\%}=12,03 \%\right)$ nego u većini dosadašnjih istraživanja. Jedino su Iqbal i dr. (2019) postigli veću točnost odnosno manju pogrešku ( $\left.\mathrm{RMSE}_{\%}=9,87 \%\right)$. Pri tome treba imati na umu da su Iqbal i dr. (2019) proveli istraživanje u plantaži P. radiata, vrlo jednostavne strukture i starosti od 29-30 godina. S druge strane u plantaži starosti 10-12 godina dobili su značajno lošije rezultate $\left(\mathrm{RMSE}_{\%}=41,38 \%\right)$. Prema tomu, prilikom usporedbe dobivenih rezultata s drugim istraživanjima potrebno je imati u vidu i tip šume odnosno strukturne i stanišne karakteristike promatranih sastojina. Također, potrebno je istaknuti da je u svim dosadašnjim istraživanjima, uz izuzetak Balenović i dr. (2017), primijenjen klasični ABA pristup (modeliranje na razini plohe) te 'wall-to-wall' mapiranje za procjenu volumena na razini sastojine. U ovom istraživanju korišten je tzv. SBA pristup koji koristi metričke podatke iz aerosnimaka za čitavu površinu odsjeka (modeliranje na razini sastojine). Budući da ne zahtijeva dodatna terenska mjerenja, već se u potpunosti bazira na postojećim podacima (aerosnimke, DMR, podaci osnove gospodarenja), predstavlja financijski značajno isplativiju alternativu klasičnom $\mathrm{ABA}$ pristupu, a uz to daje podatke slične ili čak i veće točnosti (tablica 6). SBA pristup ne može zamijeniti klasične terenske metode za potrebe uređajne inventure šuma, ali može poslužiti kao učinkovita i financijski isplativa metoda u slučajevima kada je u vrlo kratkom vremenu potrebno provesti inventuru nekog većeg šumskog područja.

\section{ZAKLJUČCI CONCLUSIONS}

U ovome radu, koji predstavlja nastavak prethodnih istraživanja (Balenović i dr. 2017), dodatno je istražena i evaluirana točnost fotogrametrijske procjene volumena na razini sastojine. Metoda je bazirana na korištenju postojećih i lako dostupnih materijala i podataka, tj. na aerosnimkama iz regularnih topografskih snimanja Republike Hrvatske, službenom digitalnom modelu reljefa te podacima iz osnove gospodarenja. Volumen sastojina procijenjen je korištenjem postojećih modela izrađenih za područje Spačvanskog bazena (SB modeli) te korištenjem istih, ali naknadno parametriziranih modela s podacima za područje Pokupskog bazena (PB modeli). Dobiveni rezultati ukazali su na značajno poboljšanje točnosti fotogrametrijske procjene volumena kod parametriziranih PB modela u odnosu na izvorne SB modele. Korijen srednje kvadratne pogreške je smanjen za značajnih $6,44 \%$, dok je srednja pogreška smanjena za $3,92 \%$ u apsolutnoj vrijednosti. U odnosu na značajnije precjenjivanje volumena korištenjem SB modela $(\approx 8,5 \%)$, korištenjem parametriziranih $\mathrm{PB}$ modela dolazi do podcjenjivanja stvarnog volumena sastojina, ali u znatno manjoj mjeri $(\approx-4 \%)$. Može se pretpostaviti da su glavni razlozi navedenim razlikama strukturne i stanišne razlike između nizinskih šuma hrasta lužnjaka Spačvanskog bazena za koje su SB modeli i njihovi parametri izrađeni te nizinskih šuma Pokupskog bazena na kojima su isti modeli i primijenjeni. Iz dobivenih rezultata daje se zaključiti da se model s pripadajućim nezavisnim varijablama koji je izvorno izrađen na području Spačvanskog bazena može koristiti i za pro- 
cjenu volumena na području Pokupskog bazena te drugih područja, ali da je u cilju poboljšanja točnosti procijene volumena sastojina uputno izraditi lokalne parametre modela. U ovome radu prikazana fotogrametrijska metoda procjene volumena sastojina ne može zamijeniti klasične terenske metode za potrebe uređajne inventure šuma. Međutim, budući da ne zahtijeva dodatna terenska mjerenja, već se u potpunosti bazira na postojećim podacima (aerosnimke, DMR, podaci osnove gospodarenja), a uz to pruža i zadovoljavajuću točnost, može poslužiti kao učinkovita i financijski isplativa metoda u slučajevima kada je u vrlo kratkom vremenu potrebno provesti inventuru nekog većeg šumskog područja. Daljnja istraživanja trebala bi biti usmjerena i na ostale varijable šumskih sastojina (npr. srednja sastojinska visina, srednji sastojinski promjer, temeljnica, broj stabala, nadzemna biomasa), kao i na druge tipove šuma odnosno šume drugih uređajnih razreda.

\section{LITERATURA}

\section{REFERENCES}

- Balenović, I., A. Seletković, R. Pernar, H. Marjanović, D. Vuletić, E. Paladinić, J. Kolić, M. Benko, 2011: Digital Photogrammetry - State of the Art and Potential for Application in Forest Management in Croatia. South-east European forestry, 2 (2): 81-93. https://doi.org/10.15177/seefor.11-09

- Balenović, I., G. Alberti, H. Marjanović, 2013: Airborne Laser Scanning - the Status and Perspectives for the Application in the South-East European Forestry. South-east European forestry, 4 (2): 59-79. https://doi.org/10.15177/seefor.13-07

- Balenović, I., A. Šimić Milas, H. Marjanović, 2017: A Comparison of Stand-Level Volume Estimates from Image-Based Canopy Height Models of Different Spatial Resolutions. Remote Sensing. 9 (3): 205. https://doi.org/10.3390/rs9030205

- Balenović, I., M. Gašparović, A. Šimić Milas, A. Berta, A. Seletković, 2018: Accuracy Assessment of Digital Terrain Models of Lowland Pedunculate Oak Forests Derived from Airborne Laser Scanning and Photogrammetry. Croatian Journal of Forest Engineering, 39 (1), 117-128.

- Balenović, I., L. Jurjević, A. Šimić Milas, M. Gašparović,D. Ivanković, A. Seletković, 2019: Testing the Applicability of the Official Croatian DTM for Normalization of UAV-based DSMs and Plot-level Tree Height Estimations in Lowland Forests. Croatian Journal of Forest Engineering, 40 (1), 163-174.

- Gašparović, M., A. Šimić Milas, A. Seletković, I. Balenović, 2018: A novel automated method for the improvement of photogrammetric DTM accuracy in forests. Šumarski list, 142 (11-12), 567-576. https://doi.org/10.31298/sl.142.11-12.1

- Gobakken, T., O. M. Bollandsås, E. Næsset, 2015: Comparing biophysical forest characteristics estimated from photogrammetric matching of aerial images and airborne laser scanning data. Scandinavian Journal of Forest Research, 30: 73-86. https://doi.org/10.1080/02827581.2014.961954

- Goodbody, T. R., N. C. Coops, J. C. White, 2019: Digital aerial photogrammetry for updating area-based forest inventories: a review of opportunities, challenges, and future directions. Current Forestry Reports, 5(2), 55-75. https://doi.org/10.1007/ s40725-019-00087-2
- Gruber, M., A. Wiechert, 2009: UltracamXP, the new digital aerial camera system by Vexcel Imaging/Microsoft. In ASPRS 2009 Annual Conference Baltimore, 13-19 March 2009., Maryland, USA.

- Hill, T., P. Lewicki, 2007: STATISTICS: Methods and Applications. StatSoft, Inc.: Tulsa, OK, USA, 800 str.

- Holopainen, M., M. Vastaranta, J. Hyyppä, 2014: Outlook for the Next Generation's Precision Forestry in Finland. Forests, 5, 1682-1694. https://doi.org/10.3390/f5071682

- Iqbal, I. A., R. A. Musk, J. Osborn, C. Stone, A. Lucieer, 2019: A comparison of area-based forest attributes derived from airborne laser scanner, small-format and medium-format digital aerial photography. International Journal of Applied Earth Observation and Geoinformation, 76, 231-241. https://doi. org/10.1016/j.jag.2018.12.002

- Lim, K., P. Treitz, M. A. Wulder, B. St-Onge, M. Flood, 2003: LiDAR remote sensing of forest structure. Progress in Physical Geography, 27: 88-106. https://doi.org/10.1191/0309133303pp360ra

- Mayer, B., 1996: Hidropedološki odnosi na području nizinskih šuma Pokupskog bazena. Radovi - Šumarski Institut, 31 (1/2): 37-89, Jastrebarsko.

- McGaughey, R.J. FUSION/LDV, 2018: Software for LiDAR Data Analysis and Visualization, Version 3.80. USDA Forest Service Pacific Northwest Research Station: Seattle, WA, USA: 209.

- Næsset, E., 2014: Area-Based Inventory in Norway-From Innovation to an Operational Reality. In Forestry Applications of Airborne Laser Scanning-Concepts and Case Studies: Maltamo, M., E. Næsset, J. Vauhkonen, Springer: Dordrecht, The Netherlands: 215-240.

- Pitt, D.G., M. Woods, M. Penner, 2015: A comparison of point clouds derived from stereo imagery and airborne laser scanning for the area-based estimation of forest inventory attributes in Boreal Ontario. Canadian Journal of Remote Sensing, 40: 214232. https://doi.org/10.1080/07038992.2014.958420

- Puliti, S., T. Gobakken, H. O. Ørka, E. Næsset, 2016: Assessing 3D point clouds from aerial photographs for species-specific forest inventories. Scandinavian Journal of Forest Research, 32, (1): 68-79. https://doi.org/10.1080/02827581.2016.1186727

- Rahlf, J., J. Breidenbach, S. Solberg, E. Næsset, R. Astrup, 2014: Comparison of four types of 3D data for timber volume estimation. Remote Sensing of Environment, 155, 325-333. https:// doi.org/10.1016/j.rse.2014.08.036

- Rahlf, J., J. Breidenbach, S. Solberg, R. Astrup, 2015: Forest parameter prediction using an image-based point cloud: a comparison of semi-ITC with ABA. Forests, 6(11), 4059-4071. https://doi.org/10.3390/f6114059

- Reutebuch, S. E., H. E. Andersen, R. J. McGaughey, 2005: Light detection and ranging (LIDAR): an emerging tool for multiple resource inventory. Journal of forestry, 103 (6), 286-292. https:// doi.org/10.1093/jof/103.6.286

- Snowdon, P., 1991: A ratio estimator for bias correction in logarithmic regressions. Canadian Journal of Forest Research, 21, 720-724. https://doi.org/10.1139/x91-101

- Stepper, S., C. Straub, H. Pretzsch, 2015: Using semi-global matching point clouds to estimate growing stock at the plot and stand levels: Application for a broadleaf-dominated forest in central Europe. Canadian Journal of Forest Research, 45, 111123. https://doi.org/10.1139/cjfr-2014-0297

- Straub, C., C. Stepper, R. Seitz, L. T. Waser, 2013: Potential of UltraCamX stereo images for estimating timber volume and basal area at the plot level in mixed European forests. Canadian Journal of Forest Research, 43, 731-741. https://doi.org/10.1139/ cjfr-2013-0125 
- White, J.C., M. A. Wulder, M. Vastaranta, N. C. Coops, D. Pitt, M. Woods, 2013: The utility of image-based point clouds for forest inventory: A comparison with airborne laser scanning. Forests, 4, 518-536. https://doi.org/10.3390/f4030518

- White, J.C., C. Stepper, P. Tompalski, N.C. Coops, M.A. Wulder, 2015: Comparing ALS and Image-Based Point Cloud Metrics and Modelled Forest Inventory Attributes in a Complex Coastal Forest Environment. Forests, 6 (10): 3704-3732. https://doi. org/10.3390/f6103704
- White, J.C., N. C. Coops, M. A. Wulder, M. Vastaranta, T. Hilker, P. Tompalski, 2016: Remote Sensing Technologies for Enhancing Forest Inventories: A Review. Canadian Journal of Remote Sensing 42 (5): 619-641. https://doi.org/10.1080/070 38992.2016.1207484

- World reference base for soil resources (WRB), 2006: A framework for international classification, correlation and communication. World Soil Resources Reports No. 103, FAO, Rome, Italy: 128.

\section{SUMMARY}

The application of digital aerial photogrammetry in forest inventory has been in the focus of a number of studies during the last decade (White et al. 2016, Goodbody et al. 2019). The results were tested and evaluated mostly on plot-level, and less often on stand-level (Bohlin et al. 2012, Rahlf et al. 2014, Gobakken et al. 2015, Pitt et al. 2015, Stepper et al. 2015, Puliti et al. 2016, Balenović et al. 2017, Iqbal et al. 2019). In almost all studies, a classic Area-Based Approach (ABA) which includes modelling at plot-level and 'wall-to-wall' mapping to estimate forest variables at stand-level were applied. A somewhat different $\mathrm{ABA}$ approach which implies direct modelling and estimation at stand-level were proposed by Balenović et al. (2017). This new approach, hereinafter referred to as Stand-Based Approach (SBA), is based on existing and easily available photogrammetric materials and data (aerial images from regular national topographic surveys, official national digital terrain data) as well as on data from existing forest management plans. The main precondition for the SBA method application is the approximate time coincidence between the time of aerial images acquisition and the time of the field data collection for the forest management plan generation. Similar to classical ABA, SBA also requires models (equations) for forest variable estimations. However, in SBA case, models are developed on the certain number of stands (subcompartments) of similar structural characteristics (e.g. forest management classes). In SBA, independent variables are metric stand-level data obtained from aerial images and its product (normalized point clouds or canopy height models), while reference (modelling or validation) data are obtained from regular forest management plans. Compared to classical ABA, SBA does not require additional field measurements, and therefore presents a fast and cost-effective alternative to ABA. An additional assumption is that models developed for the certain area can be applied for other forest areas with similar forest characteristics.

This work presents the continuation of previous study (Balenović $i$ dr. 2017) with the aim to additionally test the effectiveness and accuracy of SBA method. More precisely, SBA method and existing models of stand volume estimation originally developed for lowland pedunculate oak (Quercus robur L.) of Spačva basin forest complex (Eastern Croatia) were tested in pedunculated oak forest of Pokupsko basin forest complex (Central Croatia).

A total of 87 even-aged pedunculate oak forest stands of Jastrebarski lugovi management unit were included in this study (Figure 1, Table 1). Photogrammetric data (aerial images, digital terrain data) were provided by the Croatian State Geodetic Administration, and were used to generate Digital Surface Model (DSM) and Digital Terrain Model (DTM). A raster Canopy Height Model (CHM) of $5 \mathrm{~m}$ resolution was generated by subtracting DTM from DSM (Figure 2). Metrics extracted from CHM for each stand and used for stand-level volume estimation are presented in Table 2. Equations (1) and (2) present photogrammetric models for stand-level volume estimation. A more detailed description of the models can be found in Table 3. SB-1 and SB-2 models consist of independent variables and parameters (regression constant and coefficients) originally developed for the Spačva basin area (Table 4). PB-1 and PB-2 models consisted of the same variables as SB-1 and SB-2 models, but their parameters were developed for the present study area (Pokupsko basin) (Table 4). All models were validated using the reference stand volume from the forest management plan. SB-1 and SB-2 models were validated using the entire dataset ( 87 stands), whereas PB- 1 and PB-2 models were validated using the randomly selected 29 stands (other 58 stands were used for parameters estimation).

According to validation results (Table 2, Figure 3), $\mathrm{PB}$ models showed considerably greater performance than SB-models. Compared to SB-1 model, PB-1 model achieved $11 \%$ higher $\mathrm{R}_{\text {adj }}^{2}$ values, for $3,92 \% \mathrm{MD}_{\%}$ values (absolute), and for $6,44 \%$ higher $\mathrm{RMSE}_{\%}$ values. Also, the results showed that the inclusion of stand age (SA) as an additional predictor in SB-2 and PB-2 models did not contribute 
significantly on model performance. All models showed a similar trend (Figure 3), i.e. volume in stands with lover volume values were overestimated, while in stands with higher volume values were underestimated. However, overestimations $(\approx 8,5 \%)$ using SB models were considerably greater than underestimations $(\approx-4 \%)$ using PB models. Differences in SB and PB models performance are probably due to differences in stand and site characteristics between two forest areas (Spačva basin and Pokupsko basin). The obtained results suggest that the model with independent variables (Equation 1) originally developed for Spačva basin area can be used for Pokupsko basin and other areas with similar forest characteristics, but local model parameters have to be estimated in order to increase estimation accuracy. It has to be emphasized that the photogrammetric method tested in this paper can not replace the conventional field methods in regular forest inventory. However, its application is based on existing and easily available data (aerial images from regular topographic surveys, official DTM, forest management plan) and does not require additional field measurements and therefore present effective and low-cost solution when in a very short period large areas have to be inventoried. Further research should be focused on other important forest variables (e.g. mean stand height, mean stand diameter, basal area, stand density, biomass, etc.) and different forest types.

KEY WORDS: aerial images, digital photogrammetry, canopy height model (CHM), stand volume, forest inventory 